\title{
Selected physico-chemical properties of Serbian dry fermented sausages in different meat industries
}

\author{
Miroslav Ducic ${ }^{* 1}$, Danijela Vranic ${ }^{2}$, Milan Baltic ${ }^{3}$ \\ A b s t r a c t: Selected physico-chemical characteristics of industrially produced Sremska and Sudzuk sausages were studied to \\ complement information about the quality of typical pork and beef dry fermented products in Serbia. Analysis of production processes \\ was carried out at five meat industries. Water, lipid, protein, $\mathrm{NaCl}$, ash and nitrite contents and $\mathrm{pH}$ and water activity were determined \\ at the beginning, in the middle and at the end of the processes. The results of chemical components analyses of Sremska were uniform, \\ while Sudzuk sausages showed greater variations. However, both types of products in all examined meat industries conformed with \\ Serbian legislation for dry fermented sausages. The water activity and pH values showed the sausages can be considered as microbio- \\ logically stable products during the whole production process.
}

Keywords: Sremska, Sudzuk, physico-chemical characteristics, meat industry.

\section{Introduction}

Sremska and Sudzuk are typical Serbian dry fermented sausages (DFS) from pork and beef meat, with a long tradition of production in the country. These sausages are highly regarded among consumers and have potential for export to other countries. In industrial production, the stability and long shelf life of DFS rely on biochemical and physico-chemical changes in fermentation and drying processes. Effects of multiple antimicrobial factors, the so-called "hurdle concept", which includes adding nitrites and acidulants/starter cultures plus lowering water activity $\left(\mathrm{a}_{\mathrm{w}}\right)$, provides a hostile environment for spoilage and pathogenic microorganisms (Ducic et al., 2014). Levels of nitrites, proteins and moisture and the lowest permitted $\mathrm{pH}$ value of DFS are prescribed by official regulations (Official Gazette, 2018; Official Gazette 2015), while other aspects such as $\mathrm{a}_{\mathrm{w}}$, presence and concentration of acidulants or starter cultures, fat content, and level of $\mathrm{NaCl}$ are related to inner meat industry standards and principals of Good Manufacturing Practice.

The aim of this study was to investigate selected physico-chemical characteristics in order to complement information on the safety and quality of typical, industrially produced Serbian DFS.

\section{Materials and Methods}

Two types of DFS, Sremska and Sudzuk, produced by standard procedures including ripening without starter cultures, were investigated at five commercial meat industries (A, B, C, D, E). In industry A only, both types of sausages were investigated. Sausages were sampled at the start (day 0), at mid-process (day 8) and at the end of the process (day 15). Each sampling included 6 samples of each sausage produced (108 in total). Formulations used for DFS production are presented in Table 1. Regarding raw meat materials: producers $\mathrm{A}, \mathrm{C}$ and $\mathrm{D}$ used semi frozen meat trimmings $\left(-5^{\circ} \mathrm{C}\right.$ to $\left.-2^{\circ} \mathrm{C}\right)$; $B$ used cooled unfrozen $\left(+4^{\circ} \mathrm{C}\right)$ and frozen meat trimmings $\left(-8^{\circ} \mathrm{C}\right)$, ratio $60: 40$; E used cooled meat trimmings. Batters for pork sausages and beef sausages were stuffed into natural pork casings and collagen casings, respectively.

Physico-chemical analyses: $a_{w}$ in sausages was determined using LABSwift-aw set Euro-plug\&BAT equipment (Novasina, Switzerland); $\mathrm{pH}$ was determined by a hand-held $\mathrm{pH}$ meter (Testo 205; Germany). Both methods were according to the manufacturer's instructions.

Chemical analyses: moisture (ISO 1442, 1998); lipids (ISO 1443, 1992); proteins (ISO 937,

${ }^{1}$ University of Novi Sad, Faculty of Agriculture, Trg D. Obradovica 8, 21000 Novi Sad, Republic of Serbia

2Institute of Meat Hygiene and Technology, Kacanskog 13, 11040 Belgrade, Republic of Serbia;

${ }^{3}$ University of Belgrade, Faculty of Veterinary Medicineology, Bulevar Oslobodjenja 18,11000 Belgrade, Republic of Serbia;

*Corresponding author: Miroslav Ducic, jamerika.miroslav@gmail.com 
Table 1. Formulations used for fermented sausage production

\begin{tabular}{|c|c|c|c|c|c|c|}
\hline \multirow[t]{3}{*}{ Ingredient } & \multicolumn{3}{|c|}{ Sremska } & \multicolumn{3}{|c|}{ Sudzuk } \\
\hline & \multicolumn{6}{|c|}{ Industry } \\
\hline & $\mathbf{A}$ & B & $\mathbf{C}$ & $\mathbf{A}$ & D & $\mathbf{E}$ \\
\hline Meat trimmings & $65 \mathrm{~kg}$ & $65 \mathrm{~kg}$ & $65 \mathrm{~kg}$ & $60 \mathrm{~kg}$ & $60 \mathrm{~kg}$ & $82 \mathrm{~kg}$ \\
\hline Fatty tissue & $30 \mathrm{~kg}$ & $30 \mathrm{~kg}$ & $30 \mathrm{~kg}$ & $35 \mathrm{~kg}$ & $35 \mathrm{~kg}$ & $15 \mathrm{~kg}$ \\
\hline Spices & $\begin{array}{c}2.5 \mathrm{~kg} \\
\text { Paprika, } \\
\text { chillies, } \\
\text { coriander, } \\
\text { garlic, } \\
\text { pepper }\end{array}$ & $\begin{array}{l}2.5 \mathrm{~kg} \\
\text { Paprika, } \\
\text { chillies, } \\
\text { coriander, } \\
\text { garlic, } \\
\text { pepper }\end{array}$ & $\begin{array}{c}0.7 \mathrm{~kg} \\
\text { Paprika, } \\
\text { chillies, } \\
\text { coriander, } \\
\text { garlic, } \\
\text { pepper }\end{array}$ & $\begin{array}{c}2.0 \mathrm{~kg} \\
\text { Paprika, } \\
\text { chillies, } \\
\text { onion, pepper, } \\
\text { mustard, } \\
\text { marjoram, } \\
\text { rosemary, basil }\end{array}$ & $\begin{array}{c}0.5 \mathrm{~kg} \\
\text { Paprika, } \\
\text { chillies, } \\
\text { coriander, } \\
\text { pepper, } \\
\text { turmeric }\end{array}$ & $\begin{array}{c}0.4 \mathrm{~kg} \\
\text { Garlic, } \\
\text { pepper, } \\
\text { celery }\end{array}$ \\
\hline $\begin{array}{l}\mathrm{NaCl}: \mathrm{NaNO}_{2} \\
\text { mixture }(99.5: 0.5)\end{array}$ & $2.5 \mathrm{~kg}$ & $2.6 \mathrm{~kg}$ & $2.5 \mathrm{~kg}$ & $2.4 \mathrm{~kg}$ & $2.6 \mathrm{~kg}$ & $2.2 \mathrm{~kg}$ \\
\hline Dextrose & 0 & $0.50 \mathrm{~kg}$ & $0.35 \mathrm{~kg}$ & 0 & 0 & $0.30 \mathrm{~kg}$ \\
\hline TARI S77* & $1.0 \mathrm{~kg}$ & $1.0 \mathrm{~kg}$ & $0.6 \mathrm{~kg}$ & $1.2 \mathrm{~kg}$ & $1.0 \mathrm{~kg}$ & 0 \\
\hline
\end{tabular}

*TARI S77 - Glucono-d-lactone (GDL) 42.5\%, sugars 42.5\%, $\mathrm{NaCl} 12.5 \%$, sodium ascorbate $2.5 \%$.

1992); $\mathrm{NaCl}$ (ISO 1841-1, 1999); ash (ISO 936, 1998); $\mathrm{NaNO}_{2}$ (ISO 2918, 1999).

Statistical analysis: Determination of mean values, standard deviation and analysis of variance (ANOVA) followed by Tukey's test for the significances $(\mathrm{P}<0.05)$ of differences between grouped data was conducted by using Statistica Version 12 software (Stat Soft, Inc., Tulsa, USA).

\section{Results and Discussion}

\section{Sremska sausages}

The pHs of Sremska sausages on the first day of the production processes (Table 2) were in accordance with the results reported by Kozacinski et al. (2008) and Radulovic et al. (2011) for Sremska at the same stage of production. The exception was the initial $\mathrm{pH}$ of sausages from industry $\mathrm{B}$, with values that were considerably lower (5.0) than the other Sremska sausages studied (Table 2). Industry B used unfrozen chilled and frozen meat (see Materials and Methods), and batter prepared from these types of ingredients faster reached fermentation temperature, at which GDL is completely dissolved $\left(21-23^{\circ} \mathrm{C}\right)$. During fermentation, the activity of GDL and proliferation of lactic acid bacteria induced significant acidification of the product. Decreasing $\mathrm{pH}$ is an important inhibitory factor for constraining potential growth of Enterobacteriaceae and other pathogens and undesirable microbiota in sausages at the beginning of the ripening period, when $\mathrm{a}_{\mathrm{w}}$ is still high, as is the fermentation temperature. Therefore, on day 8, the pHs of the Sremska sausages were 0.4-0.6 units lower than the $\mathrm{pHs}$ at the beginning of production. The $\mathrm{pH}$ of the finished products was identical or slightly higher than the $\mathrm{pH}$ determined on the middle day of production (Table 2). This slight increase of $\mathrm{pH}$ in finished Sremska sausages could be induced by the release of the degradation products of proteins, as well as the decomposition of lactic acid during the remaining drying period (Salgado et al., 2006; Vukovic et al., 2004). Regarding the level of acidity, all finished Sremska sausages were classified as high-acid fermented sausages, with $\mathrm{pH}$ values lower than 5.3 (Incze, 2004).

The $\mathrm{a}_{\mathrm{w}}$ values of Sremska sausages on the start day were in accordance with the literature data for this type of product (Lücke, 2000). During fermentation and the initial drying period, $\mathrm{a}_{\mathrm{w}}$ in sausages from all three industries rapidly reduced, mainly due to the presence of the acidulant, GDL (Table 2). The dissolution of acidulant induced lowering the $\mathrm{pH}$ to the isoelectric point of the actin-myosin complex ( $\mathrm{pH}$ about 5), which leads to changes of the water distribution in the network of these two technologically most important meat proteins. Consequently, the increase in the amount of free, instead of loosely bound water facilitates its removal from the sausages, and the appropriate application of the relative 
Table 2. $\mathrm{pH}$ and $\mathrm{a}_{\mathrm{w}}$ in Sremska and Sudzuk sausages

\begin{tabular}{lccccccc}
\hline \multirow{2}{*}{$\begin{array}{c}\text { Type of } \\
\text { sausage }\end{array}$} & $\begin{array}{c}\text { Meat } \\
\text { industry }\end{array}$ & \multicolumn{3}{c}{$\mathbf{p H}$ on day } & \multicolumn{3}{c}{$\mathbf{a}_{\mathbf{w}}$ on day } \\
\cline { 3 - 8 } & $\mathrm{0}$ & $\mathbf{8}$ & $\mathbf{1 5}$ & $\mathbf{0}$ & $\mathbf{8}$ & $\mathbf{1 5}$ \\
\hline \multirow{3}{*}{ Sremska } & $\mathrm{A}$ & 5.4 & 4.9 & $5.0^{\mathrm{A} *}$ & 0.95 & 0.90 & $0.83^{\mathrm{A}}$ \\
& $\mathrm{B}$ & 5.0 & 4.9 & $5.0^{\mathrm{A}}$ & 0.96 & 0.87 & $0.77^{\mathrm{B}}$ \\
& $\mathrm{C}$ & 5.5 & 4.9 & $5.0^{\mathrm{A}}$ & 0.96 & 0.88 & $0.84^{\mathrm{A}}$ \\
& & & & & & & \\
Sudzuk & $\mathrm{A}$ & 5.4 & 4.7 & $4.8^{\mathrm{a}}$ & 0.97 & 0.92 & $0.87^{\mathrm{a}}$ \\
& $\mathrm{D}$ & 5.6 & 5.1 & $5.2^{\mathrm{b}}$ & 0.95 & 0.89 & $0.86^{\mathrm{b}}$ \\
& $\mathrm{E}$ & 5.7 & 5.3 & $5.4^{\mathrm{c}}$ & 0.96 & 0.90 & $0.88^{\mathrm{a}}$ \\
\hline
\end{tabular}

* Mean values in the same column with different letters differ significantly $(\mathrm{P}<0.05)$ within sausage type.

Statistical significance was analysed for results of the last day of production process.

humidity, temperature and air velocity parameters in the fermentation/drying chambers leads to rapid drying of the product, with a reduced risk of case-hardening (Incze, 2004). As a result, the $\mathrm{a}_{\mathrm{w}}$ of all Sremska sausages was equal to or less than 0.9 by the middle of the production processes (Day 8) (Table 2). Due largely to the combination of low $\mathrm{a}_{\mathrm{w}}$ and $\mathrm{pH}$, sausages become microbiologically stable products without conditions for the growth of most pathogenic microorganisms (USDA FSIS, 2011).
Moisture levels in Sremska sausages from all three meat industries on day 0 were similar (Table 3 ), despite the differences between industries in their use of chilled/frozen meat for sausage batter. The results of chemical analysis show that the reduction in $\mathrm{a}_{\mathrm{w}}$ was followed by a decrease in the total amount of water. In the case of producers B and C, Sremska sausages contained below $35 \%$ total water on day 8 , meaning these half-finished products would already legally fit into the category of DFS

Table 3. Chemical components (mean value $\pm \mathrm{sd}^{*}$ ) analysed during production of Sremska sausages

\begin{tabular}{ccccccc}
\hline Day & $\begin{array}{c}\text { Moisture } \\
(\%)\end{array}$ & $\begin{array}{c}\text { Lipids } \\
\mathbf{( \% )}\end{array}$ & $\begin{array}{c}\text { Proteins } \\
(\%)\end{array}$ & $\begin{array}{c}\text { NaCl } \\
(\%)\end{array}$ & $\begin{array}{c}\text { Ash } \\
(\%)\end{array}$ & $\begin{array}{c}\text { Nitrites } \\
\left(\mathbf{m g ~ k g}^{-1}\right)\end{array}$ \\
\hline & & & Industry $\boldsymbol{A}$ & & & \\
0 & $57.8 \pm 1.0$ & $16.3 \pm 1.2$ & $22.6 \pm 0.1$ & $2,2 \pm 0.0$ & $3,4 \pm 0.0$ & $136.2 \pm 3.1$ \\
8 & $38.3 \pm 1.1$ & $32.1 \pm 0.9$ & $25.9 \pm 0.3$ & $2.6 \pm 0.1$ & $3.9 \pm 0.1$ & $69.6 \pm 1.0$ \\
15 & $28.8 \pm 0.8^{\mathrm{A}}$ & $39.7 \pm 0.8^{\mathrm{B}}$ & $27.5 \pm 0.4^{\mathrm{A}}$ & $3.8 \pm 0.1^{\mathrm{A}}$ & $4.7 \pm 0.1^{\mathrm{A}}$ & $9.5 \pm 0.5^{\mathrm{A}}$ \\
& & & Industry $\boldsymbol{B}$ & & & \\
0 & $55.9 \pm 0.7$ & $18.2 \pm 0.4$ & $22.5 \pm 0.5$ & $2.2 \pm 0.1$ & $3.4 \pm 0.1$ & $139.3 \pm 2.2$ \\
8 & $34.3 \pm 0.7$ & $34.4 \pm 0.7$ & $26.8 \pm 0.5$ & $2.7 \pm 0.1$ & $3.9 \pm 0.1$ & $70.1 \pm 1.8$ \\
15 & $28.3 \pm 0.6^{\mathrm{A}}$ & $39.5 \pm 0.8^{\mathrm{B}}$ & $27.2 \pm 1.0^{\mathrm{AB}}$ & $3.6 \pm 0.1^{\mathrm{B}}$ & $4.8 \pm 0.1^{\mathrm{A}}$ & $10.3 \pm 1.1^{\mathrm{A}}$ \\
& & & Industry $\boldsymbol{C}$ & & & \\
0 & $55.7 \pm 0.6$ & $19.2 \pm 0.5$ & $21.7 \pm 0.4$ & $2.2 \pm 0.0$ & $3.4 \pm 0.0$ & $139.7 \pm 1.2$ \\
8 & $34.2 \pm 1.2$ & $35.4 \pm 0.6$ & $25.3 \pm 0.4$ & $2.7 \pm 0.1$ & $3.9 \pm 0.0$ & $71.9 \pm 0.8$ \\
15 & $28.9 \pm 0.8^{\mathrm{A}}$ & $40.2 \pm 1.1^{\mathrm{B}}$ & $26.5 \pm 0.3^{\mathrm{BC}}$ & $3.6 \pm 0.1^{\mathrm{B}}$ & $4.8 \pm 0.0^{\mathrm{A}}$ & $10.5 \pm 1.1^{\mathrm{A}}$ \\
\hline
\end{tabular}

* Mean values in the same column with different letters differ significantly $(\mathrm{P}<005)$

Statistical significance was analysed for results of the last day of production process 
at the half-way point of their production processes (Official Gazette, 2015).

The fat content in Sremska sausages at the final stage of production was lower or similar to average values of other industrially produced DFS, which rang from $40 \%$ to $50 \%$ of the total content (Olivares et al., 2010).

The total protein content of Sremska sausages was greater than $20 \%$, so these products from all three meat industries were produced in accordance with the requirements of official regulations (Official Gazette, 2015). In addition, the protein contents in our Sremska sausages were in accordance with values reported by Ferreira et al. (2007) for Portuguese sausages, but higher than values for different types of commercially produced DFS sampled from the Belgian market (De Mey et al., 2014).

Levels of $\mathrm{NaCl}$ and ash increased during fermentation and drying due to reducing water content, so the highest concentrations of these were determined on the last day of production. The values of $\mathrm{NaCl}$ in finished Sremska sausages were similar to findings for Greek DFS (Drosinos et al., 2005) and to levels of different types of sausages reported by De Mey et al. (2014). On the other hand, the final $\mathrm{NaCl}$ levels we determined were a little higher than those stated for sausages of Portuguese and Spanish origin (Fereirra et al., 2007; Salgado et al., 2006).
The initial levels of nitrite in the Sremska sausages, ranging from 136.2 to $139.7 \mathrm{mg} \mathrm{kg}^{-1}$, were in compliance with Serbian legislation (Official Gazette, 2018), where the maximum permitted added amount of sodium nitrite is $150 \mathrm{mg} \mathrm{kg}^{-1}$. Expectedly, in finished products concentrations of nitrites in all Sremska sausages were lower $\left(5-15 \mathrm{mg} \mathrm{kg}^{-1}\right)$, but within values recommended for stability during the storage period (Sindelar and Milkowski, 2011).

\section{Sudzuk sausages}

The $\mathrm{pH}$ values of Sudzuk sausages (Table 2) at the start (Table 2; day 0) were slightly higher than findings from study of Operta et al. (2012), but markedly lower than pHs reported by Kozacinski et al., (2008) for same stage of production. Generally, fermentation led to a drop of $\mathrm{pH}$ of the Sudzuk sausages from all three producers, but to varying degrees. The lowest $\mathrm{pH}$ was found in the sausages from industry $\mathrm{A}$ in the middle of production, probably due to the considerably higher amount of GDL $(1.2 \%)$ in these products than is usually expected for this additive in fermented sausages $(0.5 \%)$. On the other hand, the highest $\mathrm{pH}$ values were determined in Sudzuk sausages from industry E, where GDL was not added, but only a relatively small quantity of glucose (Table 1). Consequently, the finished products of industries $\mathrm{A}$ and $\mathrm{D}$ can be classified as

Table 4. Chemical components (mean value $\pm \mathrm{sd}^{*}$ ) analysed during production of Sudzuk sausages

\begin{tabular}{|c|c|c|c|c|c|c|}
\hline Day & $\begin{array}{l}\text { Moisture } \\
\text { (\%) }\end{array}$ & $\begin{array}{l}\text { Lipids } \\
\text { (\%) }\end{array}$ & $\begin{array}{c}\text { Proteins } \\
(\%)\end{array}$ & $\begin{array}{c}\mathrm{NaCl} \\
(\%)\end{array}$ & $\begin{array}{l}\text { Ash } \\
(\%)\end{array}$ & $\begin{array}{l}\text { Nitrites (mg/ } \\
\text { kg) }\end{array}$ \\
\hline \multicolumn{7}{|c|}{ Industry $A$} \\
\hline 0 & $52.5 \pm 0.7$ & $24.7 \pm 0.6$ & $19.3 \pm 0.8$ & $2.2 \pm 0.2$ & $3.6 \pm 0.2$ & $136.8 \pm 3.2$ \\
\hline 8 & $37.2 \pm 0.4$ & $35.3 \pm 0.9$ & $22.8 \pm 1.2$ & $3.2 \pm 0.2$ & $4.6 \pm 0.0$ & $70.5 \pm 1.8$ \\
\hline 15 & $28.0 \pm 0.4^{\mathrm{A}}$ & $40.6 \pm 0.7^{\mathrm{A}}$ & $26.4 \pm 1.4^{\mathrm{A}}$ & $3.6 \pm 0.2^{\mathrm{A}}$ & $4.7 \pm 0.2^{\mathrm{A}}$ & $7.1 \pm 0.4^{\mathrm{A}}$ \\
\hline \multicolumn{7}{|c|}{ Industry D } \\
\hline 0 & $46.2 \pm 0.6$ & $35.1 \pm 0.9$ & $15.1 \pm 1.1$ & $2.5 \pm 0.1$ & $3.6 \pm 0.1$ & $128.7 \pm 1.9$ \\
\hline 8 & $30.6 \pm 1.2$ & $44.1 \pm 1.7$ & $20.2 \pm 0.8$ & $3.9 \pm 0.1$ & $5.2 \pm 0.1$ & $78.9 \pm 1.6$ \\
\hline 15 & $23.5 \pm 0.7^{\mathrm{B}}$ & $50.4 \pm 2.5^{\mathrm{B}}$ & $21.3 \pm 1.4^{\mathrm{B}}$ & $4.1 \pm 0.2^{\mathrm{B}}$ & $5.5 \pm 0.2^{\mathrm{B}}$ & $9.8 \pm 0.4^{\mathrm{B}}$ \\
\hline \multicolumn{7}{|c|}{ Industry $E$} \\
\hline 0 & $56.4 \pm 1.1$ & $16.4 \pm 1.8$ & $23.1 \pm 1.1$ & $2.8 \pm 0.1$ & $4.1 \pm 0.1$ & $137.3 \pm 3.9$ \\
\hline 8 & $35.8 \pm 0.5$ & $33.9 \pm 0.4$ & $25.4 \pm 0.5$ & $3.6 \pm 0.1$ & $5.0 \pm 0.0$ & $71.6 \pm 1.6$ \\
\hline 15 & $32.0 \pm 0.4^{\mathrm{C}}$ & $36.5 \pm 0.4^{\mathrm{C}}$ & $26.2 \pm 0.3^{\mathrm{B}}$ & $3.9 \pm 0.1^{\mathrm{B}}$ & $5.3 \pm 0.1^{\mathrm{B}}$ & $9.2 \pm 0.7^{\mathrm{B}}$ \\
\hline
\end{tabular}

* Mean values in the same column with different letters differ significantly $(\mathrm{P}<0.05)$.

Statistical significance was analysed for results of the last day of production process. 
high-acid fermented sausages $(\mathrm{pH}<5.3)$, while industry E product satisfied the category of low-acid fermented sausages ( $\mathrm{pH}$ 5.3) (Incze, 2004). It should be noted that the $\mathrm{pH}$ of Sudzuk sausages from industry A was below 5, a minimum allowed $\mathrm{pH}$ value for DFS prescribed by Serbian legislation since 2015.

The initial $\mathrm{a}_{\mathrm{w}}$ levels in Sudzuk sausages (Table 2) were in accordance with the literature data for this sausage category and stage of production. During Sudzuk ripening, there was a noticeable decrease in the $a_{w}$, which was, however, less pronounced than in Sremska sausages. Differences in $\mathrm{a}_{\mathrm{w}}$ decrease are mainly due to variation in size of products. The diameter of the Sudzuk from industries A and D ( $\varnothing$ $38-42 \mathrm{~mm}$ ) was greater, while those from industry E were the same as the Sremska sausages (Ø 32-36 $\mathrm{mm}$ ). However, the absence of GDL in Sudzuk from industry E probably had an effect on the less pronounced decrease of $\mathrm{a}_{\mathrm{w}}$ compared to Sremska sausages. At the end of the drying process, all Sudzuk sausages had $\mathrm{a}_{\mathrm{w}}$ below 0.9 , which means they can be categorised as microbiologically stable products with long shelf life.

The results of chemical composition of finished Sudzuk sausages (Table 4) were less uniform than for Sremska sausages. Operta and Smajic (2006) also investigated the chemical composition of Sudzuk, but only from one meat industry. Their findings are closest to those from our industry A, although moisture was slightly higher and fat and protein contents lower in our investigation.

The results of initial moisture level in Sudzuk sausages showed great variations, ranging from $46.2 \%$ in sausages from industry D to $56.4 \%$ in sausages manufactured by industry E. The highest content of water (in sausages from industry E) was likely related to this company's selection of unfrozen, chilled meat for batter preparation. In finished products, water content differed significantly $(\mathrm{P}<0.05)$ between the different producers. Nevertheless, Sudzuk sausages from all three industries were in accordance with the requirements of Serbian legislation (Official Gazette, 2015), since the water content in sausages at the end of the production was less than $35 \%$, while the total protein content was greater than $20 \%$.

The fat content in Sudzuk sausages at the end of the production process also varied significantly $(\mathrm{P}<0.05)$ between industries, ranging from $36.5 \%$ to $50.4 \%$. However, all fat content levels were in the range of average fat content in commercially produced DFS.

The contents of $\mathrm{NaCl}$ and ash in Sudzuk sausages after the fermentation and drying processes were similar to or somewhat higher than in finished Sremska sausages, and these parameters were also in the range of values for dry fermented products reported in some other studies (De Mey et al., 2014; Salgado et al., 2006; Drosinos et al., 2005).

The level of added nitrite in sausages on the initial day of production was less than $150 \mathrm{mg} \mathrm{kg}^{-1}$, which is in accordance with the Serbian legislation (Official Gazette, 2018). The content of nitrite in all Sudzuk sausages at the end of the production processes varied within the recommended values, i.e. from 5 to $15 \mathrm{mg} \mathrm{kg}^{-1}$.

\section{Concluding remarks}

- pHs of sausages at the beginning of processing were in the range of usually expected values $(\mathrm{pH}$ 5.5-5.8) for that step of production. The finished products were classified as high-acid sausages $(\mathrm{pH}<5.3)$, with an exception of Sudzuk from industry E, which was a low-acid sausage $(\mathrm{pH} \geq 5.3)$;

- $\mathrm{a}_{\mathrm{w}}$ values of all sausages were 0.9 or below starting from mid-process (day 8), which categorised them as microbiologically stable products;

- moisture levels decreased gradually and at the end of process were below 35\%, meaning all sausages would be classified as dry fermented products according to official regulation;

- protein contents were higher in Sremska than in Sudzuk sausages, but in both types, protein levels were in accordance with official standards for DFS ( $\geq 20 \%)$;

- fat contents increased during ripening, reaching values of $40 \%$ in Sremska and 50\% in Sudzuk, but all were in the range of average fat contents for commercially produced DFS;

- levels of residual nitrite in all sausages at the start (day 0) were lower than the maximum permitted amount (150 $\left.\mathrm{mg} \mathrm{kg}^{-1}\right)$; at the end of process (day 15), nitrite levels accorded with recommended levels for long term stability of sausages (5-15 $\left.\mathrm{mg} \mathrm{kg}^{-1}\right)$; 


\title{
Odabrane fizičko-hemijske odlike fermentisanih suvih kobasica proizvodenih u različitim industrijama mesa u Srbiji
}

\author{
Miroslav Dučić, Danijela Vranić, Milan Z. Baltić
}

Apstrakt: Ispitane su fizičko-hemijske odlike industrijski proizvedenih sremske kobasice i sudžuka radi upotpunjavanja saznanja o kvalitetu tipičnih fermentisanih proizvoda od svinjskog i goveđeg mesa u Srbiji. Postupak proizvodnje ispitan je u pet mesnih industrija. Analiziran je sadržaj vode, masti, belančevina, $\mathrm{NaCl}$, pepela, nitrita, kao i pH i aktivnost vode kobasica, na početku, sredini $i$ završetku proizvodnog postupka. Rezultati ispitivanja hemijskog sastava sremske kobasice su ujednačeni, dok su kod sudžuka ustanovljene značajne varijacije. Bez obzira na utvrđene varijacije, u svim industrijama oba tipa proizvoda su u skladu sa važećim propisima o kvalitetu fermentisanih suvih kobasica u Srbiji. Rezultati analize aktivnosti vode i pH vrednosti ukazuju da se ispitane kobasice mogu smatrati mikrobiološki stabilnim proizvodima tokom čitavog postupka proizvodnje.

Ključne reči: sremska kobasica, sudžuk, fizičko-hemijske odlike, industrija mesa.

Disclosure statement: No potential conflict of interest was reported by authors.

Acknowledgements: The study was funded by the Ministry of Education, Science and Technological Development, Republic of Serbia (project TR31034).

\section{References}

De Mey, E., De Klerck, K., De Maere, H., Dewulf, L., Derdelinckx, G., Peeters, M. C., Peters, M., Fraeye, I., Heyden, V. Y. \& Paelinck, H. (2014). The occurrence of $\mathrm{N}$-nitrosamines, residual nitrite and biogenic amines in commercial dry fermented sausages and evaluation of their occasional relation. Meat Science, 96, 821-828.

Drosinos, E. H., Mataragas, M., Xiraphi, N., Moschonas, G., Gaitis, F. \& Metaxopulos, J. (2005). Characterisation of the microbial flora from a traditional Greek fermented sausage. Meat Science, 69, 307-317.

Ducic, M., Blagojevic, B., Markov, S., Velicanski, A. \& Buncic, S. (2014). General patterns of background microbiota and selected bacterial pathogens during production of fermented sausages in Serbia. Food Control, 43, 231-237.

Ferreira, V., Barbosa, J., Silva, J., Vendeiro, S., Mota, A., Silva, F., Monteiro, M. J., Hogg, T., Gibbs, P. \& Teixeira, P. (2007). Chemical and microbiological characterisation of "Salpicão de Vinhais" and "Chouriça de Vinhais": Tradicional dry sausages produced in the north of Portugal. Food Microbiology, 24, 618-623.

Incze, K. (2004) Sausages, types of. In C. Devine, \& M. Dikeman (Eds), Encyclopedia of Meat Sciences. Oxford, UK: Elsevier.

ISO 1841-1. (1999). Determination of chloride content-Part 1: Volhard method, 1841-1:1999. ISO, Geneva, Switzerland.

ISO 1442. (1998). Determination of moisture content, 1442:1998. ISO, Geneva, Switzerland.
ISO 2918. (1999). Determination of nitrite content, 2918:1999. ISO, Geneva, Switzerland.

ISO 937. (1999). Determination of nitrogen content, 937:1992. ISO, Geneva, Switzerland.

ISO 936. (1998). Determination of total ash, 936:1998. ISO, Geneva, Switzerland.

ISO 1443. (1999). Determination of total fat content, 1443:1992. ISO, Geneva, Switzerland.

Kozacinski, L., Drosinos, E., Caklovica, F., Cocolin, L., Gasparik-Reichardt, J. \& Veskovic, S. (2008). Investigation of microbial association of traditionally fermented sausages. Food Technology and Biotechnology, 46, 93-106.

Lücke, F. K. (2000). Fermented meats. In B. M. Lund, T. C. Baird-Parker, \& G.W. Gould (Eds.), The microbiological safety and quality of food. Gaithersburg: Aspen Publishers Inc.

Olivares, A., Navarro, J. L., Salvador, A. \& Flores, M. (2010). Sensory acceptability of slow fermented sausages based on fat content and ripening time. Meat Science, 86, 251-257.

Official Gazette. (2018). Serbia Regulation on food additives. No. No. 110-00-264/2018-10.

Official Gazette. (2015). Serbia Regulation on the quality of ground meat, meat preparations and meat products. No. 110-00-00240/2015-09.

Operta, S., Dzevdetbegovic, M., Corbo, S., Tahmaz, J. \& Sehovic, A. (2012). Fizicko-hemijska i senzorna svojstva bosanskog sudzuka proizvedenog u kontrolisanim uslovima od svezeg ohladjenog i zamrznutog govedjeg mesa. Tehnologija Mesa, 53, 2, 148-156. 
Operta, S. \& Smajic, A. (2006). Komparacija kvaliteta bosanskog sudzuka proizvedenog u domacinstvu, komunalnoj klanici i industrijskim uslovima. Tehnologija Mesa, 47, $3-4,123-130$.

Radulovic, Z., Zivkovic, D., Mirkovic, N., Petrusic, M., Stajic, S., Perunovic, M. \& Paunovic, D. (2011). Effect of probiotic bacteria on chemical composition and sensory quality of fermented sausages. Procedia Food Science, 1, $1516-1522$.

Salgado, A., García Fontán, M. C., Franco, I., López, M. \& Carballo, J. (2006). Effect of the type of manufacture (homemade or industrial) on the biochemical characteristics of Chorizo de cebolla (a Spanish traditional sausage). Food Control, 17, 213-221.

Sindelar, J. J. \& Milkowski, A. L. (2011). Sodium nitrite in processed meat and poultry meats: A review of curing and examining the risk/benefit of its use. American Meat Science Association. AMSA white paper series, No. 3.

USDAFSIS. (2011). FSIS Principles of Preservation of Shelf-Stable Dried Meat Products. https://www.fsis.usda.gov/ shared/PDF/FSRE_SS 7Principles.pdf?redirecthttp=true

Vukovic, I., Vasilev, D., Saicic, S. \& Buncic, O. (2004). Mikroflora i fizicko-hemijski pokazatelji kvaliteta kulena. Tehnologija Mesa 45 (34), 104-107.

Paper received: 13.11.2018.

Paper corrected: 30.11 .2018

Paper accepted: 27.11.2018. 